\title{
New reactions of allenes, alkynes, ynamides, enynones and isothiocyanates
}

\author{
K C KUMARA SWAMY*(D, G GANGADHARARAO, MANDALA ANITHA, \\ A LEELA SIVAKUMARI, ALLA SIVA REDDY, ADULA KALYANI and \\ SRINIVASARAO ALLU \\ School of Chemistry, University of Hyderabad, Hyderabad, Telangana 500 046, India \\ E-mail:kckssc@uohyd.ac.in; kckssc@yahoo.com
}

MS received 7 April 2018; revised 19 May 2018; accepted 25 May 2018; published online 13 July 2018

\begin{abstract}
This perspective article is related to transformations (both catalytic and non-catalytic) involving allenes, alkynes/enynones/ynamides and isothiocyanates. Part of the work from the author's group has been reviewed along with some new reactions of (i) allenylphosphonate/allenylphosphine oxide and (ii) a $\mathrm{P}(\mathrm{III})$ isothiocyanate. Thus, the allenylphosphine oxide $\mathrm{Ph}_{2} \mathrm{P}(\mathrm{O}) \mathrm{C}(\mathrm{Ph})=\mathrm{C}=\mathrm{CH}_{2}$ undergoes base (DBU) catalyzed addition to the $\beta$-ketophosphonate $\left(\mathrm{OCH}_{2} \mathrm{CMe}_{2} \mathrm{CH}_{2} \mathrm{O}\right) \mathrm{P}(\mathrm{O}) \mathrm{CH}_{2} \mathrm{C}(\mathrm{O}) \mathrm{CH}_{3}$ at $90^{\circ} \mathrm{C}$ to afford the addition product $\mathrm{Ph}_{2} \mathrm{P}(\mathrm{O}) \mathrm{C}(\mathrm{Ph})=\mathrm{C}(\mathrm{Me}) \mathrm{CH}[\mathrm{C}(\mathrm{O}) \mathrm{Me}]\left[\mathrm{P}(\mathrm{O})\left(\mathrm{OCH}_{2} \mathrm{CMe}_{2} \mathrm{CH}_{2} \mathrm{O}\right)\right]$. In an analogous reaction, with $\mathrm{DBU}$ as the base at $140{ }^{\circ} \mathrm{C}$, isomeric vinylphosphine oxides $(\mathrm{Z})-\mathrm{Ph}_{2} \mathrm{P}(\mathrm{O}) \mathrm{C}(\mathrm{Ph})=\mathrm{C}(\mathrm{Me}) \mathrm{CH}_{2}[\mathrm{C}(\mathrm{O}) \mathrm{Me}]$ and $(E)-\mathrm{Ph}_{2} \mathrm{P}(\mathrm{O}) \mathrm{C}(\mathrm{Ph})=\mathrm{C}(\mathrm{Me}) \mathrm{CH}_{2}[\mathrm{C}(\mathrm{O}) \mathrm{Me}]$ were isolated. The $E$-isomer has been characterized by single crystal X-ray structure determination. In another set of studies, the reaction of $\mathrm{P}(\mathrm{III})$ isothiocyanate $\left(\mathrm{OCH}_{2} \mathrm{CMe}_{2} \mathrm{CH}_{2} \mathrm{O}\right) \mathrm{P}(\mathrm{NCS})$ with $\mathrm{N}$-(2-bromomethyl)sulfonamide afforded an unusual product with the formula $\left(\mathrm{OCH}_{2} \mathrm{CMe}_{2} \mathrm{CH}_{2} \mathrm{O}\right) \mathrm{P}(\mathrm{O}) \mathrm{SCH}_{2} \mathrm{CH}_{2} \mathrm{NHS}(\mathrm{O})_{2}-\left(\mathrm{C}_{6} \mathrm{H}_{4}-4-\mathrm{Me}\right)$ as shown by $\mathrm{X}$-ray structure determination. This result is different from that obtained in the recently reported analogous reaction using phenyl isothiocyanate.
\end{abstract}

Keywords. Allene; allenylphosphine oxide; enynone; ynamide; P(III) isothiocyanate; X-ray structure.

\section{Introduction}

The enormous reactivity of organic substrates possessing $s p$-hybridized carbon, as in alkynes or allenes, has led to numerous synthetic methodologies. ${ }^{1}$ In many reactions involving alkynes, allenic intermediates have been proposed or isolated and in some cases this feature has been utilized as a synthetic route to specific class of allenes (cf. Figure 1). ${ }^{1,2}$ Ynamides are also a special type of alkynes in which the reactivity may depend on the ketenimium species that are analogous to allenes. ${ }^{3}$ Another class of alkynes, the enynones/enynals, also have reactivity that are typical of normal alkynes but can show additional features because of the conjugated system. ${ }^{4}$ Perhaps more interesting correlation is to a system like that of isothiocyanates (or isocyanates/ $\mathrm{CO}_{2} / \mathrm{CS}_{2}$ ) that have a

\footnotetext{
*For correspondence
}

central carbon that is $s p$-hybridized and amenable for nucleophilic attack. ${ }^{5}$ The unsaturated systems such as these are also useful in diverse catalytic transformations. Some aspects of reactions of these substrates from our research group will be highlighted in this short paper.

\section{Experimental}

Solvents were dried according to known methods as appropriate. ${ }^{6}{ }^{1} \mathrm{H},{ }^{13} \mathrm{C}$ and ${ }^{31} \mathrm{P}$ NMR spectra $\left({ }^{1} \mathrm{H}-400 \mathrm{MHz}\right.$ or $500 \mathrm{MHz},{ }^{13} \mathrm{C}-100 \mathrm{MHz}$ or $125 \mathrm{MHz}$ and $\left.{ }^{31} \mathrm{P}-162 \mathrm{MHz}\right)$ were recorded using a $400 \mathrm{MHz}$ or $500 \mathrm{MHz}$ spectrometer in $\mathrm{CDCl}_{3}$ (unless stated otherwise) with shifts referenced to $\mathrm{SiMe}_{4}(\delta=0)$. IR spectra were recorded on an FTIR spectrophotometer. Melting points were determined by using a local hot-stage melting point apparatus and are uncorrected. High-resolution mass spectra (HR-MS) were performed using a BRUKER-MAXIS mass spectrometer with ESI-QTOF-II method. 


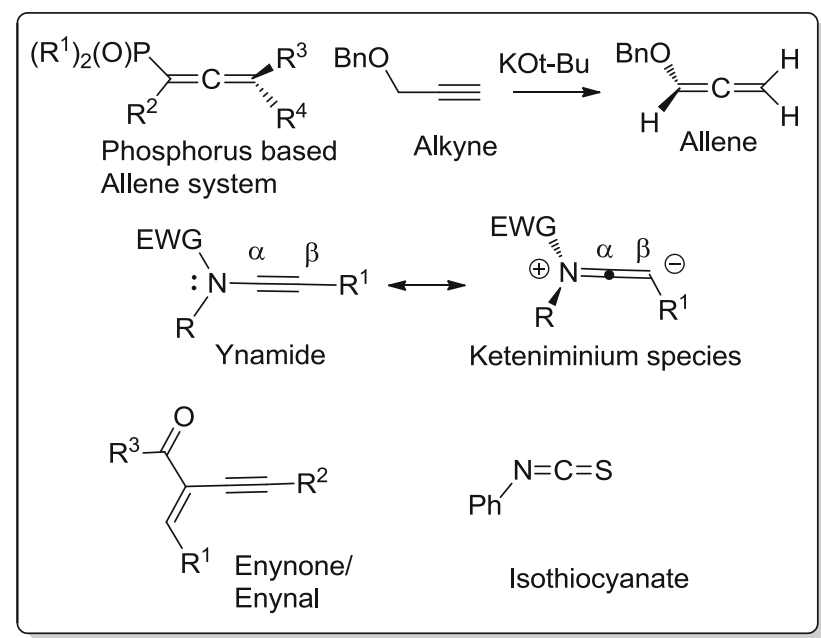

Figure 1. Some reactive species possessing central $s p$-hybridized carbon.

\subsection{Synthesis of (E)-3,5-bis(5,5-dimethyl-2-oxido- 1,3,2-dioxaphosphinan-2-yl)-4-methyl-5-phenylpent- 4-en-2-one (21) (Scheme 6)}

To an oven dried Schlenk tube, ketone $19(0.35 \mathrm{~g}, 1.70 \mathrm{mmol})$, allenylphosphonate $20(0.45 \mathrm{~g}, 1.70 \mathrm{mmol}), \mathrm{K}_{2} \mathrm{CO}_{3}(0.047 \mathrm{~g}$, $0.341 \mathrm{mmol})$ and dry DMSO $(5 \mathrm{~mL})$ were added. The contents were sealed under nitrogen atmosphere and stirred at $90{ }^{\circ} \mathrm{C}$ (oil bath temperature) for $8 \mathrm{~h}$. After completion of the reaction as monitored by TLC, the crude reaction mixture was cooled to $25^{\circ} \mathrm{C}$, diluted with ethyl acetate $(20 \mathrm{~mL})$ and washed with water. The organic layer was washed with brine solution, dried over anhyd. $\mathrm{Na}_{2} \mathrm{SO}_{4}$ and concentrated under vacuum. The residue was purified by using silica gel column chromatography with hexane-ethyl acetate (3:7) as the eluent to afford (E)-3,5-bis(5,5-dimethyl-2-oxido1,3,2-dioxaphosphinan-2-yl)-4-methyl-5-phenylpent-4-en-2one (21). Compound 21: Yield: $0.309 \mathrm{~g}(68 \%)$; gummy liquid; IR (KBr): 3057, 2973, 2886, 1809, 1715, 1605, 1472, 1373, 1283, 1071, 916, 829, 735, 704, $635 \mathrm{~cm}^{-1} ;{ }^{1} \mathrm{H}$ NMR (400 $\left.\mathrm{MHz}, \mathrm{CDCl}_{3}\right) \delta$ 7.38-7.27 (m, 3H), 7.19 (br m, 2H), 6.38 $(\mathrm{d}, J=24.8 \mathrm{~Hz}, 1 \mathrm{H}), 4.62(\mathrm{~d}, J=11.2 \mathrm{~Hz}, 1 \mathrm{H}), 4.53$ $(\mathrm{d}, J=11.2 \mathrm{~Hz}, 1 \mathrm{H}), 3.97-3.82(\mathrm{~m}, 4 \mathrm{H}), 3.62(\mathrm{t}, J=$ $12.0 \mathrm{~Hz}, 1 \mathrm{H}), 3.32(\mathrm{t}, J=13.4 \mathrm{~Hz}, 1 \mathrm{H}), 2.41(\mathrm{~s}, 3 \mathrm{H})$, $1.91(\mathrm{~s}, 3 \mathrm{H}), 1.30(\mathrm{~s}, 3 \mathrm{H}), 0.95(\mathrm{~s}, 6 \mathrm{H}), 0.52(\mathrm{~s}, 3 \mathrm{H}) ;{ }^{13} \mathrm{C}$ NMR $\left(100 \mathrm{MHz}, \mathrm{CDCl}_{3}\right) \delta 199.3,151.6(J=10.4,5.5 \mathrm{~Hz})$, $136.6(J=9.0 \mathrm{~Hz}), 130.8(J=164.9,12.1 \mathrm{~Hz}, \mathrm{P}-C)$, $130.0129 .8,128.6,127.8,76.1(J=6.4 \mathrm{~Hz}), 75.8(J=$ $6.1 \mathrm{~Hz}), 57.4(J=6.3 \mathrm{~Hz}), 56.2(J=6.3 \mathrm{~Hz}), 56.8$ $(J=117.5,6.3 \mathrm{~Hz}, \mathrm{P}-C), 32.6(J=7.2 \mathrm{~Hz}), 32.3$ $(J=6.6 \mathrm{~Hz}), 30.3,22.1,21.7,21.2(J=16.4 \mathrm{~Hz}), 20.7$, $20.4 ;{ }^{31} \mathrm{P}\left\{{ }^{1} \mathrm{H}\right\} \mathrm{NMR}\left(162 \mathrm{MHz}, \mathrm{CDCl}_{3}\right) \delta 11.7(J=6.0 \mathrm{~Hz})$, $10.7(J=5.8 \mathrm{~Hz})$; LC/MS: $m / z 471\left[\mathrm{M}^{+}+\mathrm{H}\right]$; Anal. Calcd. $\mathrm{C}_{22} \mathrm{H}_{32} \mathrm{O}_{7} \mathrm{P}_{2}$ : C, 56.17; H, 6.86\%; Found: C, 56.31, $\mathrm{H}, 6.81 \%$. HRMS (ESI): Calcd. for $\mathrm{C}_{22} \mathrm{H}_{33} \mathrm{O}_{7} \mathrm{P}_{2}\left[\mathrm{M}^{+}+\mathrm{H}\right]$ : $\mathrm{m} / \mathrm{z}$ 471.1702. Found: 471.1703 .
2.2 Synthesis of (E)-3-(5,5-dimethyl-2-oxido-1,3,2dioxaphosphinan-2-yl-5 (diphenylphosphoryl)4-methyl-5-phenylpent-4-en-2-one (23)(Scheme 6)

To an oven dried Schlenk tube, ketone $19(0.17 \mathrm{~g}, 0.80 \mathrm{mmol})$, allene $22(0.25 \mathrm{~g}, 0.80 \mathrm{mmol})$ and DBU $(0.025 \mathrm{~g}, 0.16 \mathrm{mmol})$ in dry DMSO $(5 \mathrm{~mL})$ were added. The contents were sealed under nitrogen atmosphere and stirred at $90{ }^{\circ} \mathrm{C}$ (oil bath temperature) for $8 \mathrm{~h}$. The work up and isolation of the compound were similar to that given above using hexane-ethyl acetate (7:3) as the eluent to afford (E)-3-(5,5-dimethyl-2-oxido1,3,2-dioxaphosphinan-2-yl-5 (diphenylphosphoryl)-4-methyl-5-phenylpent-4-en-2-one (23). Compound 23: Yield: $0.250 \mathrm{~g}(60 \%)$; gummy liquid $\sim 95 \%$ purity ; IR (KBr): 3063 , 2973, 2926, 1717, 1481, 1420, 1370, 1285, 1117, 1057, 1013, 791, 756, 725, $700 \mathrm{~cm}^{-1}$; ${ }^{1} \mathrm{H}$ NMR $\left(400 \mathrm{MHz}, \mathrm{CDCl}_{3}\right) \delta$ 7.68-7.63 (m, 2H), 7.48-7.32 (m, 4H), 7.26-7.21 (m, 4H), 7.14-7.01 (m, 7H), 6.99-6.79 (m, 3H), 6.39 (d, $J=6.8 \mathrm{~Hz}$, $1 \mathrm{H}), 4.88-4.82(\mathrm{~m}, 2 \mathrm{H}), 4.02-3.84(\mathrm{~m}, 2 \mathrm{H}), 2.14(\mathrm{~s}, 3 \mathrm{H})$, $1.92(\mathrm{~s}, 3 \mathrm{H}), 1.19$ (s, 3H), 1.02 (s, 3H); ${ }^{13} \mathrm{C}$ NMR $(100 \mathrm{MHz}$, $\left.\mathrm{CDCl}_{3}\right) \delta 200.0,151.2,137.5(\mathrm{~J}=11.6 \mathrm{~Hz}), 133.3,132.2$, $131.9(J=10.4 \mathrm{~Hz}), 131.6(J=10.4 \mathrm{~Hz}), 131.5,130.6$ $(J=106.5 \mathrm{~Hz}, \mathrm{P}-C), 130.3,129.4,128.9,128.8,128.4$, $128.2,127.7,127.6,127.1,122.8,93.9,82.0,77.2(\mathrm{~d}, J=$ $8.7 \mathrm{~Hz}), 65.5,56.7(J=109.1 \mathrm{~Hz}, \mathrm{P}-C), 32.8(J=7.2 \mathrm{~Hz})$, 31.5, 30.4, 29.7, $22.3(J=11.4 \mathrm{~Hz}), 22.2,20.4 .,{ }^{31} \mathrm{P}\left\{{ }^{1} \mathrm{H}\right\}$ NMR $\left(162 \mathrm{MHz}, \mathrm{CDCl}_{3}\right) \quad \delta 31.7(\mathrm{~d}, J=4.1 \mathrm{~Hz}), 12.3$ $\left(\mathrm{d}, J=4.1 \mathrm{~Hz}\right.$ ); LC/MS $m / z 471\left[\mathrm{M}^{+}+\mathrm{H}\right]$. HRMS (ESI): Calcd. for $\mathrm{C}_{29} \mathrm{H}_{33} \mathrm{O}_{5} \mathrm{P}_{2}\left[\mathrm{M}^{+}+\mathrm{H}\right]: m / z$ 523.1804. Found: 523.1804

\subsection{Synthesis of (Z)-5-(diphenylphosphoryl)-4-} methyl-5-phenylpent-4-en-2-one (24) and (E)-5(diphenylphosphoryl)-4-methyl-5- phenylpent-4-en-2one (25) (Scheme 6)

To an oven dried Schlenk tube, allene $22(0.50 \mathrm{~g}, 1.58 \mathrm{mmol})$, ethyl acetoacetate $(0.31 \mathrm{~g}, 2.37 \mathrm{mmol})$, DBU ( $0.048 \mathrm{~g}, 0.31$ $\mathrm{mmol})$, DMSO $(5 \mathrm{~mL})$ were added. The contents were sealed under nitrogen atmosphere and heated with stirring at $140{ }^{\circ} \mathrm{C}$ (oil bath temperature) for $6 \mathrm{~h}$. The work up was similar to above and the compounds $(Z)-5$-(diphenylphosphoryl)-4methyl-5-phenylpent-4-en-2-one $\left(\mathbf{2 4}\right.$; higher $\left.\mathrm{R}_{\mathrm{f}}\right)$ and $(E)$ 5-(diphenylphosphoryl)-4-methyl-5-phenylpent-4-en-2-one $\left(\mathbf{2 5}\right.$; lower $\mathrm{R}_{\mathrm{f}}$ ) were isolated using hexane-ethyl acetate (4:6) as the eluent. Compound 24: Yield: $0.172 \mathrm{~g}(29 \%$, purity $>95 \%$ ); gummy liquid; IR (KBr): 3057, 2922, 1715, $1678,1609,1487,1437,1358,1316,1173,1115,1026$, $754 \mathrm{~cm}^{-1} ;{ }^{1} \mathrm{H}$ NMR $\left(400 \mathrm{MHz}, \mathrm{CDCl}_{3}\right) \delta 7.57-7.52(\mathrm{~m}, 5 \mathrm{H})$, 7.40-7.38 (m, 2H), 7.32-7.27 (m, 5H), 7.04-7.02 (m, 3H), 6.79-6.77 (m, 2H), 4.18 (s, 2H), 2.04 (s, 3H), 1.73 (s, 3H); ${ }^{13} \mathrm{C}$ NMR $\left(100 \mathrm{MHz}, \mathrm{CDCl}_{3}\right) \delta 205.7,151.8(J=6.1 \mathrm{~Hz})$, $138.2(J=11.2 \mathrm{~Hz}), 132.8(J=103.0 \mathrm{~Hz}, \mathrm{P}-C), 131.7$, $131.6,131.3,131.2,131.0,130.1_{1}, 130.0_{7}, 128.5,128.1$, $127.9,126.7,50.1(J=6.8 \mathrm{~Hz}), 30.1,24.2(J=11.5 \mathrm{~Hz})$; ${ }^{31} \mathrm{P}\left\{{ }^{1} \mathrm{H}\right\}$ NMR $\left(162 \mathrm{MHz}, \mathrm{CDCl}_{3}\right) \delta$ 28.9; LC/MS m/z 375 
$\left[\mathrm{M}^{+}+\mathrm{H}\right]$. HRMS (ESI): Calcd. for $\mathrm{C}_{24} \mathrm{H}_{24} \mathrm{O}_{2} \mathrm{P}\left[\mathrm{M}^{+}+\mathrm{H}\right]$ : $m / z$ 375.1515. Found: 375.1515.

Compound 25: Yield: $0.207 \mathrm{~g}$ (35\%); white solid, M.p.: $172-176{ }^{\circ} \mathrm{C}$; IR (KBr): 3048, 2924, 1715, 1678, 1609, 1478, 1437, 1358, 1315, 1173, 1115, 1026, $754 \mathrm{~cm}^{-1} ;{ }^{1} \mathrm{H}$ NMR $\left(400 \mathrm{MHz}, \mathrm{CDCl}_{3}\right) \delta$ 7.66-7.61 (m, 4H), 7.40-7.38 (m, 2H), $7.32-7.27(\mathrm{~m}, 4 \mathrm{H}), 6.99-6.96(\mathrm{~m}, 3 \mathrm{H}), 6.80(\mathrm{~d}, J=6.8 \mathrm{~Hz}$, $2 \mathrm{H}), 3.19(\mathrm{~s}, 2 \mathrm{H}), 2.25(\mathrm{~d}, J=2.8 \mathrm{~Hz}, 3 \mathrm{H}), 2.01(\mathrm{~s}, 3 \mathrm{H})$; ${ }^{13} \mathrm{C}$ NMR $\left(100 \mathrm{MHz}, \mathrm{CDCl}_{3}\right) \delta 205.6,151.0(J=7.8 \mathrm{~Hz})$, 134.4, 133.4, $133.3(J=103.0 \mathrm{~Hz}, \mathrm{P}-C), 132.0,131.9$, $131.3,129.4,128.2,128.1,126.9,52.6(J=11.6 \mathrm{~Hz})$, 30.3, $23.0(J=7.5 \mathrm{~Hz}) ;{ }^{31} \mathrm{P}\left\{{ }^{1} \mathrm{H}\right\} \mathrm{NMR}\left(162 \mathrm{MHz}, \mathrm{CDCl}_{3}\right) \delta$ 29.2; LC/MS m/z $375\left[\mathrm{M}^{+}+\mathrm{H}\right]$; Anal. Calcd. $\mathrm{C}_{24} \mathrm{H}_{23} \mathrm{O}_{2} \mathrm{P}$ : C, 76.99; H, 6.19\%; Found: C, 77.1, H, 6.15\%. HRMS (ESI): Calcd. for $\mathrm{C}_{24} \mathrm{H}_{24} \mathrm{O}_{2} \mathrm{P}\left[\mathrm{M}^{+}+\mathrm{H}\right]: \mathrm{m} / z$ 375.1515. Found: 375.1517.

\subsection{Synthesis of $N-(2-((5,5-D i m e t h y l-2-o x i d o-1,3,2-$ dioxaphosphinan-2-yl)thio)ethyl)-4-methylbenzene sulfonamide (48) (Scheme 13)}

$N$-(2-Bromoethyl) sulfonamide $45(0.36 \mathrm{mmol})$ and 3((isothiocyanato(methyl)phosphino)oxy)-2,2-dimethylpropan-1-ol 47 (0.54 mmol) were used. Yield $0.118 \mathrm{~g}(86 \%$, white solid); M.p.: $136-138{ }^{\circ} \mathrm{C}$; IR (KBr) $v_{\max } 3175,2974$, 1324, 1262, 1155, 1092, 1050, 1000, 835, 782, $732 \mathrm{~cm}^{-1}$; ${ }^{1} \mathrm{H}$ NMR $\left(400 \mathrm{MHz}, \mathrm{CDCl}_{3}\right) \delta$ 7.71-7.69 (m, 2H), 7.24 $(\mathrm{d}, J=8.0 \mathrm{~Hz}, 2 \mathrm{H}), 6.19(\mathrm{br}, 1 \mathrm{H}), 4.08(\mathrm{~d}, J=$ $12.0 \mathrm{~Hz}, 2 \mathrm{H}), 3.90-3.83(\mathrm{~m}, 2 \mathrm{H}), 3.20-3.18$ (m, 2H), 2.95$2.92(\mathrm{~m}, 2 \mathrm{H}), 2.36(\mathrm{~s}, 3 \mathrm{H}), 1.21(\mathrm{~s}, 3 \mathrm{H}), 0.83(\mathrm{~s}, 3 \mathrm{H})$; ${ }^{13} \mathrm{C}$ NMR $\left(100 \mathrm{MHz}, \mathrm{CDCl}_{3}\right) \delta 143.2,137.1,129.7,127.0$, $78.1(J=5.5 \mathrm{~Hz}), 43.6(J=2.1 \mathrm{~Hz}), 32.4(J=$ $6.0 \mathrm{~Hz}), 29.4,21.8,21.4,20.2 ;{ }^{31} \mathrm{P}$ NMR (162 $\left.\mathrm{MHz}, \mathrm{CDCl}_{3}\right)$ $\delta$ 20.74; HRMS (ESI) calcd. for $\mathrm{C}_{14} \mathrm{H}_{22} \mathrm{NO}_{5} \mathrm{PS}_{2} \mathrm{Na}\left(\mathrm{M}^{+}+\mathrm{Na}\right)$ 402.0575, found: 402.0575. This compound was crystallized from dichloromethane/ethyl acetate (2:1) mixture at $25{ }^{\circ} \mathrm{C}$.

\section{$2.5 X$-ray structural analysis of compounds 25 and 48}

Single crystal X-ray data for compounds 25 and $\mathbf{4 8}$ were collected on a Bruker AXS-SMART or OXFORD diffractometer using Mo- $\mathrm{K}_{\alpha}(\lambda=0.71073 \AA)$ radiation. The structures were solved by direct methods and refined by full-matrix least squares method using standard procedures. ${ }^{7}$

Compound 25: $\mathrm{C}_{24} \mathrm{H}_{23} \mathrm{O}_{2} \mathrm{P}, \mathrm{M}=374.39$, monoclinic, space group $P 22_{1} / \mathrm{n}, a=11.9638(7) \AA, b=10.6625(5) \AA$, $c=16.0875(8) \AA, \beta=93.956(5)^{\circ}, V=2047.30(17) \AA^{3}, Z$ $=4, \mu=0.150 \mathrm{~mm}^{-1}$, data/restraints/parameters 3598/0/246, $\mathrm{R}$ indices $(\mathrm{I}>2 \sigma(\mathrm{I})) \mathrm{R} 1=0.0454, \mathrm{wR} 2$ (all data) $=0.1145$. CCDC no. 1834021.

Compound 48: $\mathrm{C}_{14} \mathrm{H}_{22} \mathrm{NO}_{5} \mathrm{PS}_{2}, \mathrm{M}=379.42$, triclinic, space group $P-1, a=6.8296(8) \AA, b=7.4875(8) \AA$, $c=18.4067(19) \AA, \alpha=80.149(5), \beta=81.744(5), \gamma=$ 82.580(4), $V=912.47(17) \AA^{3}, \mathrm{Z}=2, \mu=0.440 \mathrm{~mm}^{-1}$, data/restraints/parameters 3205/4/214, R indices (I > $2 \sigma(\mathrm{I})$ ) $\mathrm{R} 1=0.1064$, wR2 (all data) $=0.2825$. The quality of data was only moderate, but the refinement could be satisfactorily done. CCDC no. 1575674.

\section{Results and Discussion}

\subsection{Reactivity of allenylphosphonates/allenyl- phosphine oxides}

Selected reactions of allenylphosphonates/allenylphosphine oxides reported from our laboratory are shown in Scheme $1 .{ }^{8}$ Many of these have been summarized in a recent article. ${ }^{8 \mathrm{a}}$ While performing these reactions we were also curious to see whether some intermediates can be isolated. For example, in the reaction shown in Scheme 2a, two equivalents of the thiophosphite $\left(\mathrm{OCH}_{2} \mathrm{CMe}_{2} \mathrm{CH}_{2} \mathrm{O}\right) \mathrm{P}(\mathrm{S}) \mathrm{H}$ (2) can be added (cf. compound 5) on to the allene 1 in the presence of $\operatorname{Pd}\left(\mathrm{PPh}_{3}\right)_{4}$, but in a blank reaction in the absence of allene, we could isolate the $[\mathrm{Pd}]$ species $\mathbf{6}$ (Scheme $2 \mathrm{~b}$ ). Interestingly, this compound $\mathbf{6}$ was also very effective in catalyzing the same phosphonylation reaction. ${ }^{8 \mathrm{~b}}$

In another study, we were investigating the phosphonylation reactions of allenylphosphonates and BaylisHillman adducts using tetrabutylammonium fluoride $\left[(n-\mathrm{Bu})_{4} \mathrm{NF}\right]$ as the catalyst in ionic liquid [bmim $]^{+}$ $\left[\mathrm{PF}_{6}\right]^{-}$as the medium (Scheme 3). ${ }^{9}$ It is important to note that pentacoordinate phosphorus intermediates are proposed in numerous reactions involving tetracoordinate phosphorus. However, they have been rarely been identified spectroscopically. In the present case, we have been able to elegantly identify such an intermediate [Scheme 3b; case (ii)] by the combined use of ${ }^{31} \mathrm{P},{ }^{1} \mathrm{H}$ and ${ }^{19} \mathrm{~F}$ NMR spectroscopy wherein the values of ${ }^{1} J P F[959.5 \mathrm{~Hz}$, ${ }^{1} \mathrm{JPH}[652.4 \mathrm{~Hz}]$ and ${ }^{2} J \mathrm{FH}[129.4 \mathrm{~Hz}]$ could be easily discerned. ${ }^{9}$ The ${ }^{1} \mathrm{H}$ NMR and ${ }^{13} \mathrm{C}$ NMR spectra were also consistent with the phosphocin ring being intact.

In another interesting reaction of allenes wherein both phosphine and gold catalysis is involved, we chose an allenoate 10. Thus, in a one-pot reaction, the allenoate $\mathbf{1 0}$ reacted with the enynal 11 to afford trisubstituted benzofuran 13 via cyclopentene intermediate 12 (Scheme 4). ${ }^{10}$ For the first step in the formation of the cyclopentenes 12, initial attack of the phosphine on the allenoate $\mathbf{1 0}$ can be envisaged. However, to date, the exact species of type $\mathbf{1 4}$ has not been characterized. The closest that we have been able to isolate and structurally characterize are the compounds 16' and 16" using the Inorganic ring system $\left[(t-\mathrm{BuNH}) \mathrm{P}[\mathrm{N}(t-\mathrm{Bu})]_{2} \mathrm{P}(\mathrm{NH}-t-\mathrm{Bu})\right](\mathbf{1 5}) .{ }^{11}$ Thus attack of the trivalent phosphorus on the central $s p$-hybridized $\beta$-carbon of the allene affords $\mathbf{1 6}$ which 
<smiles>[R12]C(=O)c1c(C([Y10])C)[nH]c2ccccc12</smiles><smiles>[R]c1cc2ccccc2nc1C([R2])(C(=O)c1ccccc1)[PH]([R16])=O</smiles><smiles>[R20]C1([R])C(=C)n2c(c(Cl)c3ccccc32)C1O</smiles>

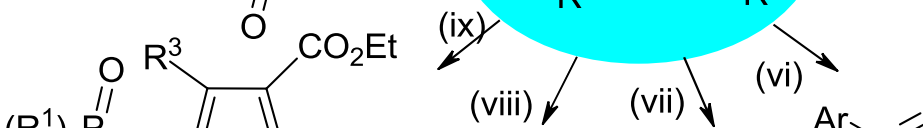

(v)

(ii)

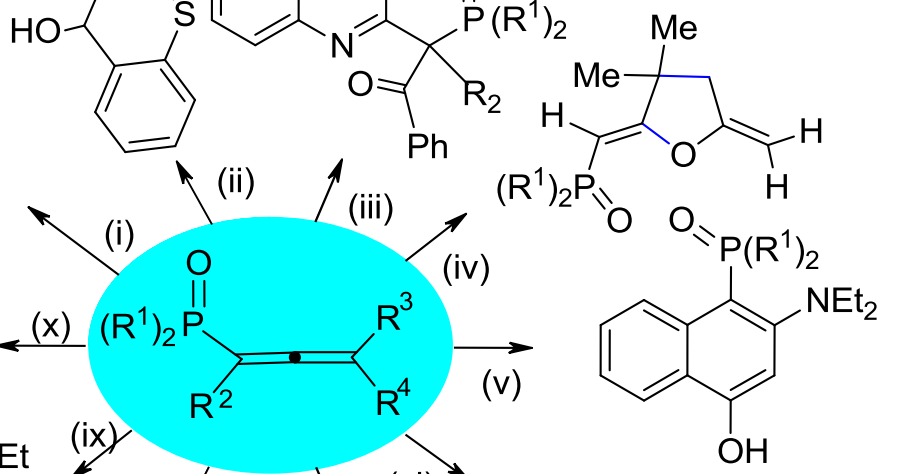
$\left(R^{1}\right)_{2}$<smiles>[R2]C1c2[nH]c(C)c(C)c2C[NH+]1[Y6]</smiles>

(viii)<smiles>[R2]C([R2])C1=C([PH]([R17])=O)c2ccccc2CO1</smiles>

Scheme 1. Cyclization/cycloaddition reactions of allenylphosphonates/allenylphosphine oxides. Conditions: (i) $\mathrm{K}_{3} \mathrm{PO}_{4}$ (0.5 equiv.), THF, $80{ }^{\circ} \mathrm{C}, 12 \mathrm{~h} / \mathrm{NaOH}$ (2 equiv.), $\mathrm{EtOH} / \mathrm{H}_{2} \mathrm{O}$ (4:1), $80{ }^{\circ} \mathrm{C}, 8 \mathrm{~h}$; ${ }^{8 \mathrm{a}}$ (ii) $\mathrm{K}_{2} \mathrm{CO}_{3}(20 \mathrm{~mol} \%)$, DMSO, $90{ }^{\circ} \mathrm{C}, 4 \mathrm{~h} ;{ }^{8 e}$ (iii) $\mathrm{K}_{3} \mathrm{PO}_{4}(20 \mathrm{~mol} \%$ ), DMSO, $120{ }^{\circ} \mathrm{C}, 8-12 \mathrm{~h} ;{ }^{8 \mathrm{a}}$ (iv) Propargylic alcohols, $\mathrm{Zn}(\mathrm{OTf})_{2}(10 \mathrm{~mol} \%), \mathrm{Et}_{3} \mathrm{~N}(20 \mathrm{~mol} \%)$, toluene, $100{ }^{\circ} \mathrm{C}, 8 \mathrm{~h} ;{ }^{8 \mathrm{c}}$ (v) $\mathrm{Et}_{2} \mathrm{NH}, \mathrm{CH}_{3} \mathrm{CN}$, rt $\left(25^{\circ} \mathrm{C}\right), 8 \mathrm{~h} ;{ }^{8 \mathrm{a}}$ (vi) $\mathrm{K}_{2} \mathrm{CO}_{3}(20 \mathrm{~mol} \%)$, DMSO, $90{ }^{\circ} \mathrm{C}, 24$ h, ${ }^{8 \mathrm{e}}$ (vii) $\mathrm{ZrCl}_{4}$ (0.5 mol equiv.), $\mathrm{MeOH}$, reflux, 2-3 h, ${ }^{8 \mathrm{a}}$.(viii) $\mathrm{Me}_{3} \mathrm{SiN}_{3}, \mathrm{CH}_{3} \mathrm{CN}$, reflux, 18-20 $\mathrm{h} ;{ }^{8 f}$ (ix) $\mathrm{Me}_{3} \mathrm{SiN}_{3}, \mathrm{DMF} / \mathrm{CH}_{3} \mathrm{C}(\mathrm{O}) \mathrm{CH}_{2} \mathrm{CO}_{2} \mathrm{Et}, \mathrm{Mn}(\mathrm{OAc})_{3}, \mathrm{MeOH}, \mathrm{rt}^{8}{ }^{8 \mathrm{a}}$ (x) $\mathrm{K}_{2} \mathrm{CO}_{3}(20 \mathrm{~mol} \%$ ), PEG-400, $90{ }^{\circ} \mathrm{C}, 4 \mathrm{~h} .{ }^{8 \mathrm{~d}}$.

(a)

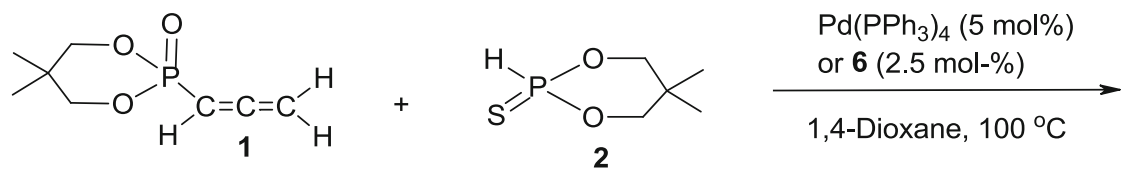<smiles>CC1(C)COP(=O)(CP2(=S)/C=C\C(C)(C)OCC(C)(C)CO2)OC1</smiles>

3<smiles>CC(C)(C)COP(=O)(OCC(C)(C)COP(=S)(OCC(C)(C)C)OCC(C)(C)C)C(CP(=S)(OCC(C)(C)C)OCC(C)(C)C)P(=S)(OCC(C)(C)C)OCC(C)(C)C</smiles>

4

5 Combined yield: $>80 \%$

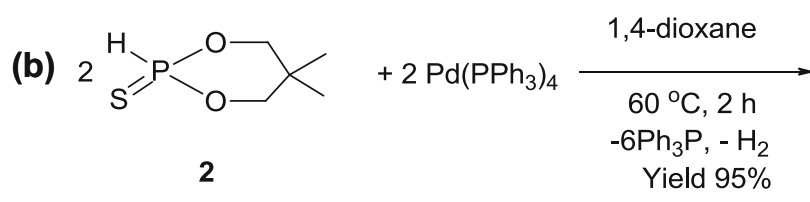

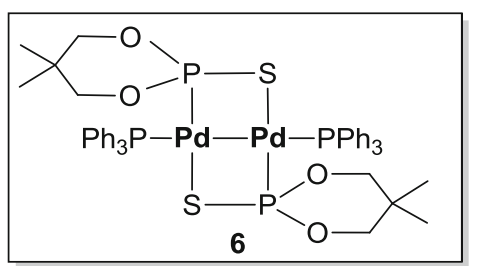

$\delta(P): 15.3,148.0\left(\mathrm{~d}\right.$ each, $\left.{ }^{2} J(\mathrm{PP})=12.2 \mathrm{~Hz}\right)$

Scheme 2. [Pd]-catalyzed thiophosphonylation of allenylphosphonate $\mathbf{1}$ and isolation of the catalytically active intermediate $\mathbf{6}$.

then rearranges to $16^{\prime} / \mathbf{1 6}$ '. Conversion of cyclopentene $\mathbf{1 2}$ to the benzofuran $\mathbf{1 3}$ is also complex but is assumed to involve the $[\mathrm{Au}]$-intermediates 17/17' (Scheme 5).
Sterically unhindered allenylphosphonates are susceptible to attack by water and thus $\left(\mathrm{OCH}_{2} \mathrm{CMe}_{2} \mathrm{CH}_{2} \mathrm{O}\right)$ $\mathrm{P}(\mathrm{O}) \mathrm{CH}=\mathrm{C}=\mathrm{CH}_{2} \mathbf{1 8}$ can be converted to the $\beta$-ketophos- 
(a)

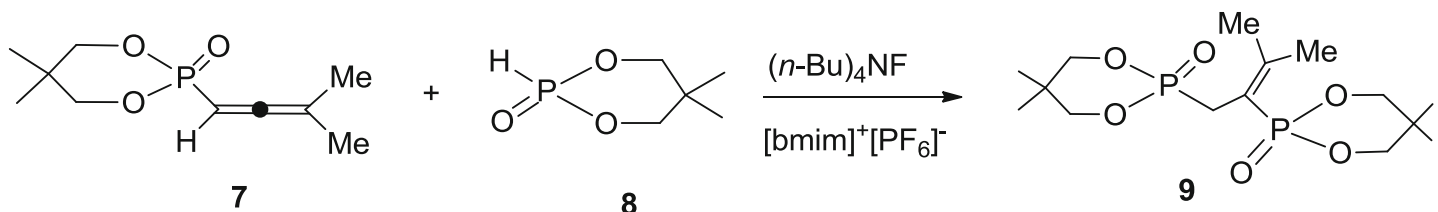

(b)

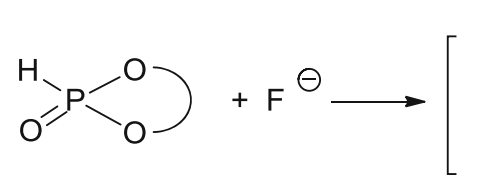<smiles>[O-][PH]1(F)OCCO1</smiles><smiles>CC1CCCC1</smiles><smiles>[O-][PH]1(F)OCCO1</smiles>

Active pentacoordinate species/intermediate (i)<smiles>C#CCO</smiles><smiles>CC(CO)(CO)CO</smiles><smiles>Cc1cc(Cc2cc(C)cc(C(C)(C)C)c2O)c(O)c(C(C)(C)C)c1</smiles>

Scheme 3. The $\left[(n-\mathrm{Bu})_{4} \mathrm{NF}\right]$ mediated/catalyzed addition of a phosphite to allenylphosphonate showing the pentacoordinate phosphorus species.
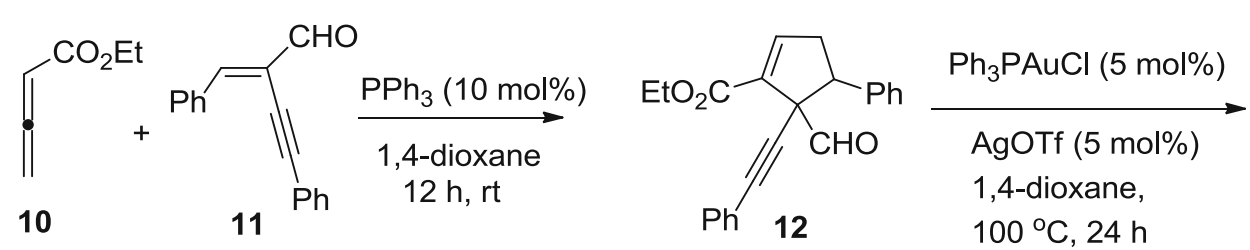<smiles>CCOc1cccc(-c2ccccc2)c1Oc1ccccc1</smiles>

Scheme 4. One pot $\mathrm{PPh}_{3}$ and $[\mathrm{Au}]$-catalyzed reaction of allenoate with enynal for the formation of multiply substituted benzofuran.

(a)

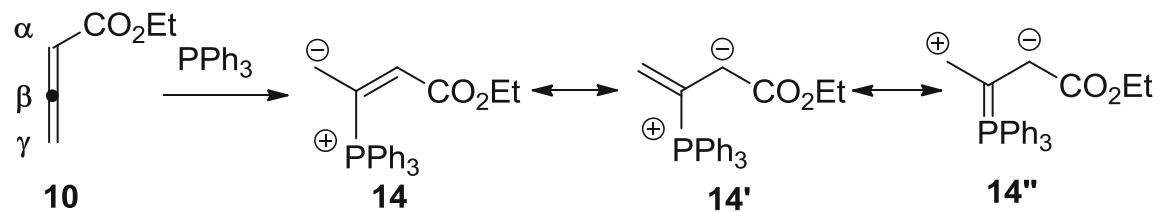

(b)

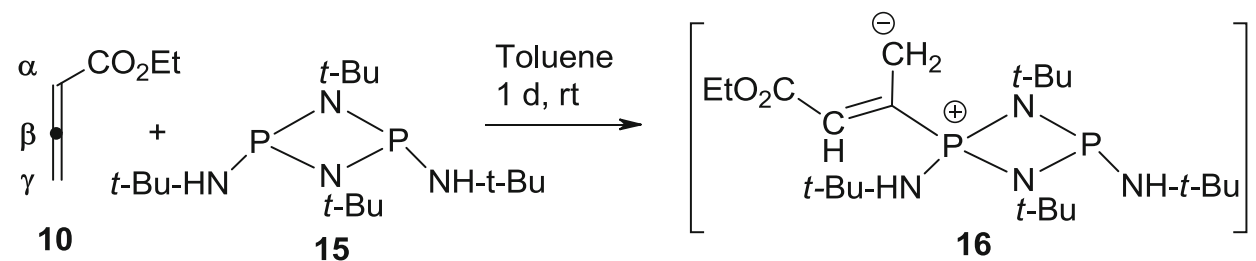

10

15<smiles>C=C(CC(C)(C)C)P(=NC(C)(C)C)(N(PNC(C)(C)C)C(C)(C)C)N(C(C)(C)C)C(C)(C)C</smiles>

16' [X-ray]

$16 "$ [X-ray]

(c)

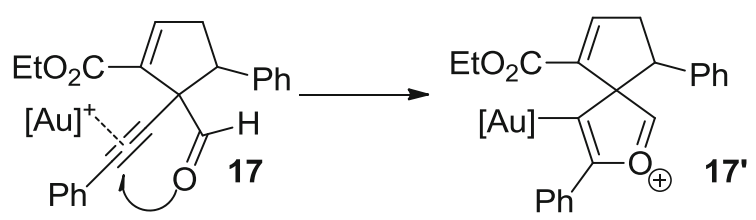

Scheme 5. (a) Possible intermediates in the phosphine catalyzed reaction of allenoate; (b) Isolation of intermediate-type species using cyclodiphosphazane and; (c) Two plausible intermediates in the $[\mathrm{Au}]$ catalyzed reaction of alkyne substituted cyclopentenes. 
(a)

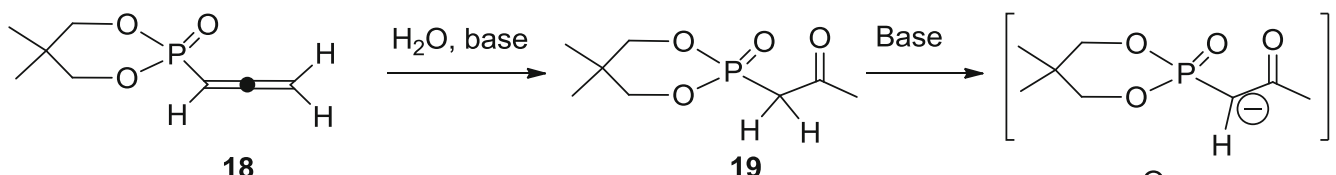

18

$$
19
$$

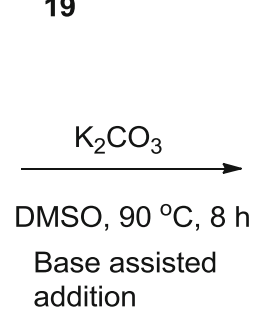

(b)<smiles>CC(=O)C([18OH])[13CH2][13CH3]</smiles><smiles>C=COP(=O)(OCC(C)(C)C)C(=O)c1ccccc1</smiles><smiles>CC1(C)COP(=O)(O)OC1</smiles>

21

Yield $68 \%$<smiles>CC=O</smiles><smiles>CC(=O)C(/C(C)=C(\c1ccccc1)P(=O)(c1ccccc1)c1ccccc1)P(=O)(OCC(C)(C)C)OCC(C)(C)C</smiles>

(c)<smiles>CC(=O)C([18OH])[P+]([O])([18OH])OCC(C)(C)C</smiles><smiles>O=P(c1ccccc1)(c1ccccc1)c1ccccc1</smiles><smiles>COC(=O)O[Mg]</smiles>

Yield $60 \%$

(d)

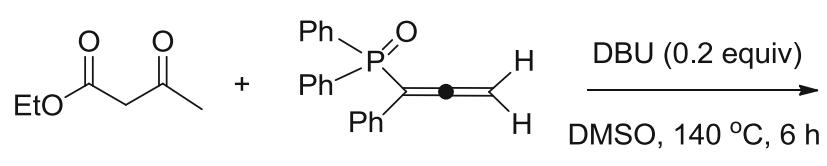

22<smiles>[Z]C(C)=C(P(=O)(c1ccccc1)c1ccccc1)P(=O)(c1ccccc1)c1ccccc1</smiles>

24<smiles>CC(=O)CC(C)=C(P(=O)(F)c1ccccc1)P(=O)(c1ccccc1)c1ccccc1</smiles>

25 (X-ray)

Scheme 6. (a) Formation of $\beta$-ketophosphonate 19 from allenylphosphonate 18; (b)-(c) reactions of allenylphosphonate 20 and allenylphosphine oxide 22 with $\beta$-ketophosphonate 19 to afford 23; (d) reaction of allenylphosphine oxide 22 with ethyl acetoacetate to afford 24-25.

phonate $\left(\mathrm{OCH}_{2} \mathrm{CMe}_{2} \mathrm{CH}_{2} \mathrm{O}\right) \mathrm{P}(\mathrm{O}) \mathrm{CH}_{2} \mathrm{C}(\mathrm{O}) \mathrm{CH}_{3}(\mathbf{1 9})^{12}$ in the presence of a base. Since compound 19 can take part in Horner-Wadsworth reaction, we envisaged that the anion thus obtained should act as a nucleophile towards the central $s p$-hybridized carbon of the allenylphosphonate of type $\mathbf{2 0}$. Indeed this reaction did occur and we could readily isolate the bisphosphonate 21. A similar reaction occurred using the allenylphosphine oxide 22 and phosphonate-phosphine oxide $\mathbf{2 3}$ was obtained in decent yields. In the latter case though, we used DBU as the base. Interestingly, in the reaction of allenylphosphine oxide 22 with ethyl acetoacetate, we obtained a different set of products, the isomeric 24-25 in which the ester moiety was removed probably via adventitious moisture present in the system. The X-ray structure of the $E$-isomer, 25 has been determined (Figure 2). It is possible that the olefinic double bond may shift itself to give enone isomers in these cases. Indeed in the reaction of 22 with ethyl acetoacetate in the presence of $\mathrm{K}_{2} \mathrm{CO}_{3}$ or DABCO such isomers appear to form, ${ }^{13}$ but these reactions need to be studied further in order to get insight into the mechanistic details as well as utility.

\subsection{Alkyne enynone/enynal/ynamide reactivity}

As mentioned above (cf. Figure 1) both alkyne and allene have a reactive $s p$-hybridized carbon. One of the

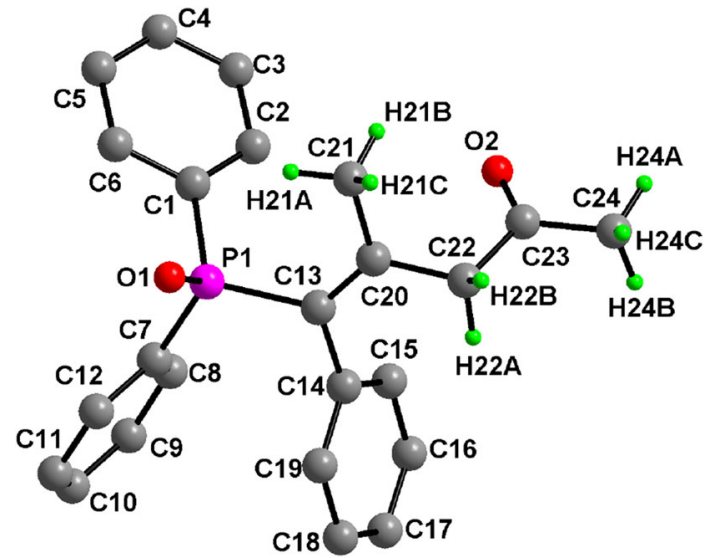

Figure 2. Molecular structure of compound 25 showing the $E$-configuration. Only selected hydrogen atoms are shown. Selected bond distances (A) with esds: P1-O1 1.486(1), P1-C7 1.796(2), P1-C1 1.809(2), P1-C13 1.821(2), C13-C20 1.341(3), C20-C22 1.500(3), C20-C21 1.510(3). CCDC No. 1834021.

reactions that we investigated is the double arylation of alkynes. ${ }^{14}$ Analogous reactions are generally carried out in the presence of $\left[\mathrm{Pd}\left(\mathrm{PPh}_{3}\right)_{4}\right]$ in a nonaqueous solvent. ${ }^{15}$ Interestingly, we could effect this reaction of the alkyne 26 on water within a very short time using the palladium catalyst 6 alluded to before (cf. Scheme 7), 
<smiles>CC1(C)COP(=O)(C#Cc2ccccc2)OC1</smiles>
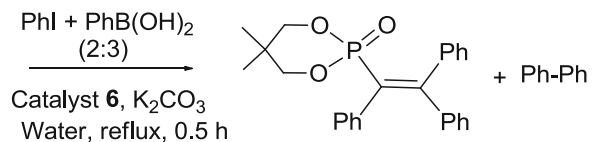

26

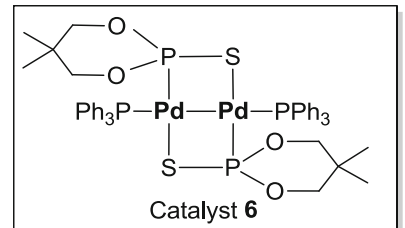

Scheme 7. Double arylation of alkyne 26 using our catalyst 6 on water to afford 27.

giving rise to the double arylated product $27 .{ }^{14}$ The reaction could be readily monitored by ${ }^{31} \mathrm{P}$ NMR spectroscopy which suggested that catalyst $\mathbf{6}$ is more efficient than the traditional $\left[\mathrm{Pd}\left(\mathrm{PPh}_{3}\right)_{4}\right]$ and readily afforded clean products.

In a significant number of reactions involving alkyne insertion, the ruthenium catalyst $\left[\mathrm{RuCl}_{2} \text { ( } p \text {-cymene) }\right]_{2}$ is used. ${ }^{16}$ The substrate generally has a directing group (e.g., 8-aminoquinoline). In reactions such as these, it is generally assumed that both the chlorines of $\left[\mathrm{RuCl}_{2}(p \text {-cymene })\right]_{2}$ are replaced under catalytic conditions. However, for the annulation reaction shown in Scheme 8, we found that only one of the chlorines on the catalyst/pre-catalyst $\left[\mathrm{RuCl}_{2}(p \text {-cymene })\right]_{2}$ gets replaced in the absence of the substrate $\mathbf{2 8}$ to afford the complex $[\mathrm{RuCl}(\mathrm{OAc})(p$-cymene $)](\mathbf{3 0})$. What is more interesting is that this intermediate 30 reacts with $N$-quinolin-8-ylbenzamide $\mathbf{2 8}$ to give the ruthenium complex $\mathbf{3 1}$ that can also act as a catalyst for the alkyne insertion. ${ }^{17}$ Thus,

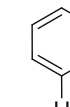

(a)<smiles>NCCNc1[c]cccc1</smiles>

${ }^{\mathrm{H}}$

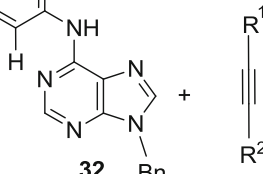

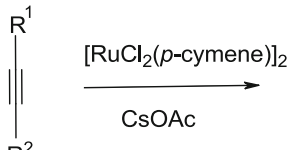<smiles></smiles>

(b)<smiles>Cc1ccccc1Nc1ncnc2c1ncn2Br</smiles>

$\left[\mathrm{RuCl}_{2}(p \text {-cymene) }]_{2}\right.$

$\mathrm{NaOAc}$

32

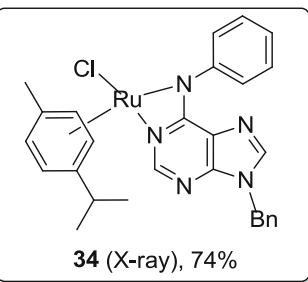

Scheme 9. [Ru]-catalyzed alkyne insertion onto purine base appended aniline via $\mathrm{C}-\mathrm{H}$ activation.
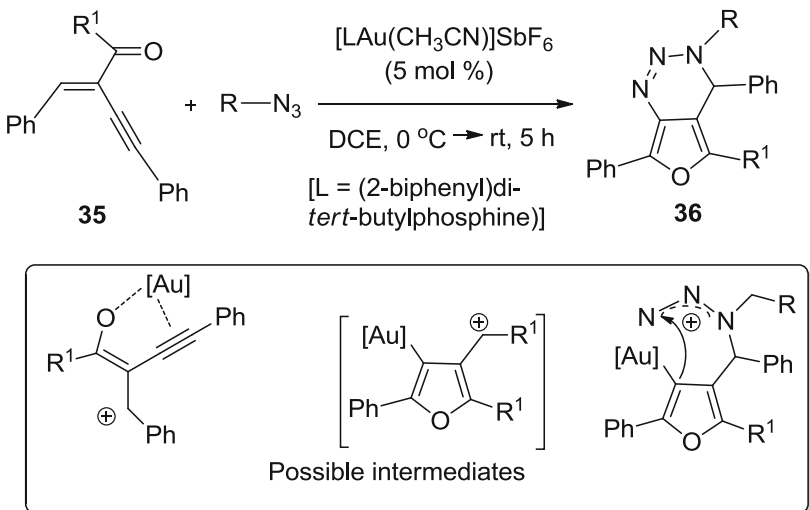

Scheme 10. Gold-catalyzed the formation of triazine fused furans; the possible intermediates are also shown.

this study suggested that there may be other (previously not formulated) intermediates for this alkyne insertion reaction. (a)<smiles>O=C(c1ccccc1)N(I)c1cccc2c[cH+]ccnc12</smiles>

(b)

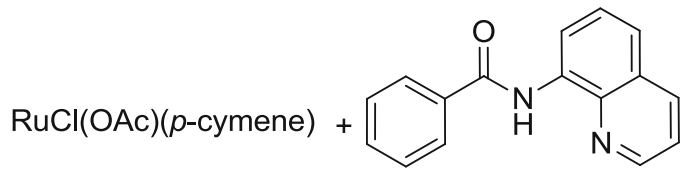
30 (1 equiv) 28 (1 equiv)

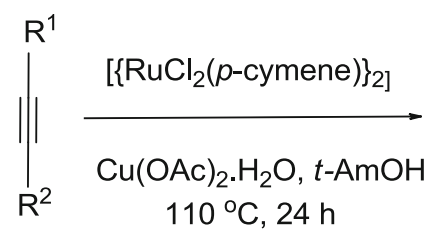

$t-\mathrm{AmOH}$ $110^{\circ} \mathrm{C}, 24 \mathrm{~h}$<smiles>[R]c1c([R])n(-c2cccc3cccnc23)c(=O)c2ccccc12</smiles><smiles>Cc1ccc(C(C)C)c(Cl)c1N(C)C(=O)c1ccccc1N(C)c1cccc2cccc(Cl)c12</smiles>

31 (X-ray) (also active as catalyst)

Scheme 8. (a) Alkyne insertion using the ruthenium catalyst/precatalyst $\left[\mathrm{RuCl}_{2} \text { ( } p \text {-cymene) }\right]_{2}$ and (b) isolation of an intermediate type ruthenium complex $\mathbf{3 1}$. 
(a)<smiles>[Y6]N(C=Cc1ccccc1)S(=O)(=O)c1ccc(C)cc1I</smiles>
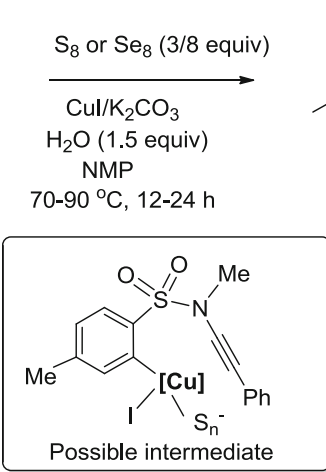



(b)

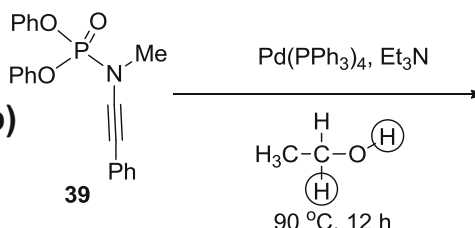

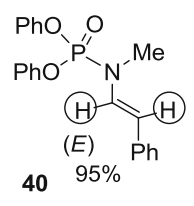

Scheme 11. (a) Sulfur/selenium insertion reaction of ynamides and; (b) $E$-selective hydrogenation of ynamides using ethanol as the hydrogenating agent.

In another alkyne insertion reaction on the substrate $\mathbf{3 2}$ leading to the annulated product $\mathbf{3 3}$ shown in Scheme 9 , we have used purine as the directing group. ${ }^{18}$ In a manner similar to that shown in Scheme 8, we were able to isolate the ruthenium complex 34 . Such an observation suggests that in these reactions $\left[\mathrm{RuCl}_{2}(p\right.$ cymene) $]_{2}$ acts only as a pre-catalyst.

Enynones/enynals have double bonds, generally in conjugation with the alkyne moiety. This structural feature may impart new type of reactivity for such a substrate. One such example reported from our group using

the alkynophilic $[\mathrm{Au}]$ catalysts is shown in Scheme 10. ${ }^{19}$ Here, the reaction of azide with the enynone/enynal under gold catalysis leads to the formation of a 6membered triazine ring compound, rather than the familiar click reaction in which a triazole is obtained. The main condition for this to happen is that the group $\mathrm{R}^{1}$ has to be aromatic. Several $[\mathrm{Au}]$-intermediates are involved in this process; three of them are shown in the scheme.

Ynamides belong to a special type of alkynes in which the reactivity of the two $s p$-hybridized carbon atoms of the alkyne exhibit vastly different reactivity. ${ }^{3}$ One example in which we could insert elemental sulfur or selenium directly into the ring system via copper catalysis is demonstrated in Scheme 11a. ${ }^{20}$ Here, the initial reaction of $\mathrm{CuI}$ with the iodo-substituted ynamide is assumed to lead to an intermediate in which the copper is connected to the arene [cf. Scheme 11a). The sulfur $\left[\mathrm{S}_{n}\right]^{2-}$ (or similar selenide) anion is produced from sulfur in the presence of the base $\mathrm{K}_{2} \mathrm{CO}_{3}$ and water. Perhaps a more interesting reaction of the ynamide is catalytic hydrogenation using ethanol as the hydrogenating agent under palladium catalysis. An example of this is shown in Scheme $11 \mathrm{~b} .{ }^{21}$ Here, the $E$-enamide is formed preferentially.

\subsection{Isothiocyanate reactivity}

Carbon disulfide $(\mathrm{S}=\mathrm{C}=\mathrm{S})$, as well as aryl isothiocyanates $\mathrm{ArN}=\mathrm{C}=\mathrm{S}$, have a central $s p$-hybridized carbon which is susceptible to nucleophilic attack. ${ }^{5}$ In this sense, this system is analogous to the allene system described above (cf. Figure 1). We have been interested
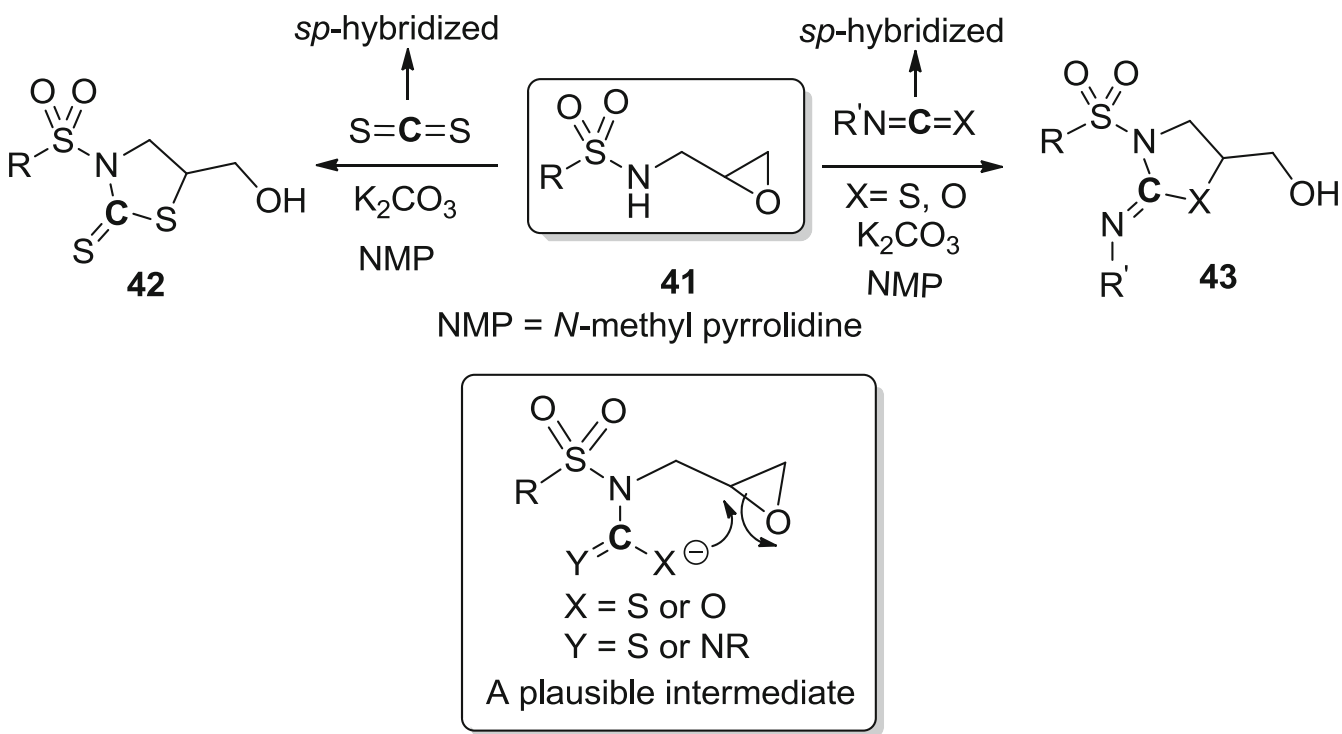

Scheme 12. Base-mediated reaction of cumulenes $\left(\mathrm{CS}_{2} / \mathrm{PhNCS}\right)$ with epoxy sulfonamides. 
(a)

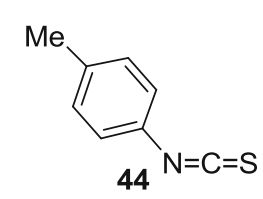

(b)<smiles>CC1(CI)CO[Pb](N=C=S)OC1</smiles>

47

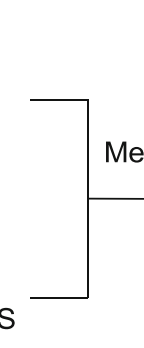

NMP, $80^{\circ} \mathrm{C}, 12 \mathrm{~h}$
(Base mediated)

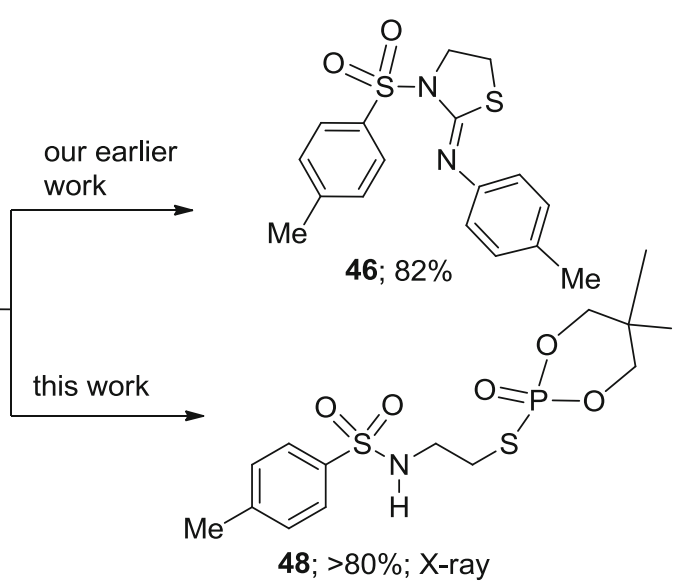

Scheme 13. (a) Reaction of aryl isothiocyanate $\mathbf{4 4}$ with bromoethylsulfonamide $\mathbf{4 5}$ to afford $\mathbf{4 6}$; (b) Unusual reaction of bromoethyl-sulfonamide with P(III) isothiocyanate $\mathbf{4 7}$ to afford $\mathbf{4 8}$.

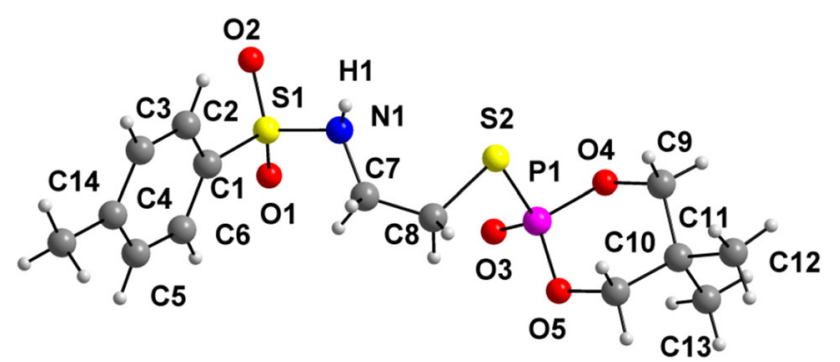

Figure 3. Molecular structure of compound 48. The data quality was only moderate in this case. Selected bond lengths $[\AA]$ with esds in parentheses: N1-C7 1.404(8), C8-C7 1.398(9), S2-C8 1.777(7), P1-S2 2.052(4), P1-O3 1.427(7), N1-H1 0.751(11), S1-N1 1.583(10). CCDC no. 1575674.

in extending the chemistry of allenes to include carbon disulfide or isothiocyanates/isocyanates. An example from a recent report is shown in Scheme 12. ${ }^{22}$ In this case, a nucleophile is generated by the removal of $\mathrm{NH}$ proton from 41 in the presence of the base; this nucleophile attacks the $s p$-hybridized carbon center of carbon disulfide or isothiocyanate/isocyanate in a manner analogous to that with central carbon of allenes. Subsequent cyclization/epoxide ring opening and the addition of proton leads to the final products of types $\mathbf{4 2 - 4 3}$.

In our earlier work on P(III) compounds, we had noted that $\mathrm{P}$ (III) azides react in a manner different from organic azides. ${ }^{23 \mathrm{a}-\mathrm{b}}$ Hence, to know whether a P(III) isothiocyanate 47 will react in a manner similar to the traditional organic isothiocyanate 44 (Scheme 13a, cf. product 46), we treated the precursor 47 with the bromoethyl-sulfonamide $\mathbf{4 5}$. This reaction did take place, but in a direction entirely different from the above, leading to the product $\mathbf{4 8}$. In this case, the formation of new $\mathrm{P}-\mathrm{S}$ and $\mathrm{C}-\mathrm{S}$ bonds has taken place in addition to the oxidation at the phosphorus center. IR,
NMR $\left({ }^{1} \mathrm{H}\right.$ and $\left.{ }^{13} \mathrm{C}\right)$ and HRMS data are consistent with the structure shown below (Scheme 13b). The structure of compound $\mathbf{4 8}$ was also confirmed by X-ray crystallography (Figure 3). More investigations, though, are needed to rationalize this observation.

\section{Conclusions}

Recent work on the reactions of allenylphosphonates/ allenylphosphine oxides, alkynes, enynones, ynamides and isothiocyanates has been summarized. In a new set of reactions, it is shown that allenylphosphonates/allenylphosphine oxides undergo addition reactions with $\beta$-ketophosphonate to lead to products in which the nucleophilic attack at the central $s p$-hybridized carbon of the allene is involved. In a slightly different pathway, allenylphosphine oxide (e.g., 22) reacted with ethyl acetoacetate to afford isomeric vinylphosphine oxides with the elimination of the ester moiety in the presence of adventitious moisture. It is also shown that the reactivity of a $\mathrm{P}(\mathrm{III})$ isothiocyanate is different from the reaction of traditional organic isothiocyanates.

\section{Supplementary Information (SI)}

Spectroscopic data for the new compounds reported here will be available from the authors. Crystallographic data for $\mathbf{2 5}$ and 48 have been deposited with the Cambridge Crystallographic Data Centre as supplementary publication numbers CCDC 1834021 and 1575674. Copies of the data can be obtained free of charge, on application to CCDC, 12 Union Road, Cambridge CB2 1EZ, UK [fax: +44(1223)336033 or email: deposit@ccdc.cam.ac.uk]. Supplementary information is available at www.ias.ac.in/chemsci. 


\section{Acknowledgements}

We thank the Department of Science and Technology (DST, New Delhi; FIST, PURSE Phase II) and the University Grants Commission (UGC, New Delhi; NRC, SAP) for financial support and equipment. KCK thanks CSIR (New Delhi for a project (02(0240)/15/EMR-II) and DST for the J. C. Bose fellowship (SR/S2/JCB-53/2010).

\section{References}

1. (a) Kumara Swamy K C, Siva Reddy A, Sandeep K and Kalyani A 2018 Advances in chemoselective and/or stereoselective semihydrogenation of alkynes Tetrahedron Lett. 59 419; (b) Fang G and Bi X 2015 Silvercatalysed reactions of alkynes: Recent advances Chem. Soc. Rev. 44 8124; (c) Dorel R and Echavarren A M 2015 Gold(I)-catalyzed activation of alkynes for the construction of molecular complexity Chem. Rev. 115 9028; (d) Yamamoto Y 2014 Synthesis of heterocycles via transition-metal catalyzed hydroarylation of alkynes Chem. Soc. Rev . 43 1575; (e) Alcaide B and Almendros P 2014 Progress in allene chemistry Chem. Soc. Rev. 43 2886; (f) Cui C, Shan C, Zhang Y, Chen X, Qu L and Lan Y 2018 Mechanism of phosphine-catalyzed allene coupling reactions: Advances in theoretical investigations Chem. Asian J. 131076

2. (a) Ye J and Ma S 2014 Palladium-catalyzed cyclization reactions of allenes in the presence of unsaturated carbon-carbon bonds Acc. Chem. Res. 47 989; (b) Krause N and Winter C 2011 Gold-catalyzed nucleophilic cyclization of functionalized allenes: A powerful access to carbo- and heterocycles Chem. Rev. 111 1994; (c) Aubert C, Fensterbank L, Garcia P, Malacria M and Simonneau A 2011 Transition metal catalyzed cycloisomerizations of 1,n-allenynes and -allenenes Chem. Rev. 111 1954; (d) Wei L L, Xiong H and Hsung R P 2013 The emergence of allenamides in organic synthesis Acc. Chem. Res. 36 773; (e) Ma S 2009 Electrophilic addition and cyclization reactions of allenes Acc. Chem. Res. 42 1679; (c) Yu S and Ma S 2012 Allenes in catalytic asymmetric synthesis and natural product synthesis Angew. Chem. Int. Ed. 513074

3. (a) Prabagar B, Nayan Ghosh N and Sahoo A K 2017 Cyclization and Cycloisomerization of $\pi$-tethered ynamides: An expedient synthetic method to construct carbo- and heterocycles Synlett. 28 2539; (b) Peng Q and Paton R S 2016 Catalytic control in cyclizations: From computational mechanistic understanding to selectivity prediction Acc. Chem. Res. 49 1042; (c) Wang X N, Yeom H S, Fang L C, He S, Ma Z X, Kedrowski B $\mathrm{L}$ and Hsung R P 2014 Ynamides in ring forming transformations Acc. Chem. Res. 47 560; (c) Lu T and Hsung R P 2014 Novel ynamide structural analogues and their synthetic transformations Arkivoc i 127

4. (a) Leela Siva Kumari A, Siva Reddy A and Kumara Swamy K C 2016 Exploring the gold mine: [Au]catalysed transformations of enynals, enynones and enynols Org. Biomol. Chem. 14 6651; (b) Obradors C and Echavarren A M 2014 Gold-catalyzed rearrangements and beyond Acc. Chem. Res. 47 902; (c) Dorel R and Echavarren A M 2015 Gold(I)-catalyzed activation of alkynes for the construction of molecular complexity Chem. Rev. 115 9028; (d) Garayalde D and Nevado C 2012 Gold-containing and gold-generated 1,n-dipoles as useful platforms toward cycloadditions and cyclizations ACS Catal. 21462

5. (a) Mukerjee A K and Ashare R 1991 Isothiocyanates in the chemistry of heterocycles Chem. Rev. 91 1; (b) Kitanosono T, Masuda K, Xu P and Kobayashi S 2018 Catalytic organic reactions in water toward sustainable society Chem. Rev. 118679

6. Armarego W L F and Perrin D D 1996 In Purification of Laboratory Chemicals $4^{\text {th }}$ edn. (Oxford: ButterworthHeinemann)

7. (a) Sheldrick G M 1996 SADABS, Siemens Area Detector Absorption Correction, University of Göttingen, Germany; (b) Sheldrick G M 1997 SHELX-97: A program for crystal structure solution and refinement, University of Göttingen, Germany; (c) Sheldrick G M 1999 SHELXTL NT Crystal Structure Analysis Package, Version 5; Bruker AXS Analytical X-ray System, WI (USA)

8. (a) Kumara Swamy K C, Anitha M, Gangadhararao G and Rama Suresh R 2017 Exploring allene chemistry using phosphorus-based allenes as scaffolds Pure Appl. Chem. 89 367; (b) Srinivas V, Balaraman E, Sajna K V and Kumara Swamy K C 2011 Catalystfree and catalysed addition of $\mathrm{P}(\mathrm{O})-\mathrm{H}$ bonds to allenyl/alkynyl-phosphonates and -phosphane oxides: Use of a robust, recoverable dinuclear palladium(I) catalyst Eur. J. Org. Chem. 4222; (c) Srinivas V, Sajna K V and Kumara Swamy K C 2011 Zn(OTf) 2 catalyzed addition-cyclization reaction of allenylphosphine oxides with propargyl alcohol-unexpected formation of 2,5dimethylenetetrahydrofurans and 2-substituted furans Tetrahedron Lett. 52 5323; (d) Phani Pavan M and Kumara Swamy K C 2011 Stereoselective synthesis of pyrrolo[1,2-a]indoles from allenes in PEG-400 as the reaction medium Synlett. 9 1288; (e) Phani Pavan M, Nagarjuna Reddy M, Bhuvan Kumar N N and Kumara Swamy K C 2012 Base catalysed synthesis of thiochromans and azo-linked chromenes using allenylphosphonates Org. Biomol. Chem. 10 8113; (f) Chakravarty M, Bhuvan Kumar N N, Sajna K V and Kumara Swamy K C 2008 Allenylphosphonates-Useful precursors of pyrazoles and 1,2,3-triazoles Eur. J. Org. Chem. 4500

9. Balaraman E, Srinivas V and Kumara Swamy K C 2009 Hydrophosphonylation of activated alkenes and alkynes via fluoride ion activation in ionic liquid media Tetrahedron 657603

10. Leela Siva Kumari A and Kumara Swamy K C 2015 Divergence in the reactivity between amineand phosphine-catalyzed cycloaddition reactions of allenoates with enynals: One-pot gold-catalyzed synthesis of trisubstituted benzofurans from the [3+2] cycloadduct via 1,2-alkyl migration and dehydrogenation J. Org. Chem. 804084

11. Bhuvan Kumar N N and Kumara Swamy K C 2008 The reaction of allenes with phosphorus(III) compounds bearing a P-NH- $(t-\mathrm{Bu})$ group: Isolation of both enantiomers in crystalline form from an achiral system Tetrahedron Lett. 497135 
12. Bhuvan Kumar N N, Chakravarty M, Satish Kumar N, Sajna K V and Kumara Swamy K C 2009 Allenylphosphonates with a 1,3,2-dioxaphosphorinane ring: Synthesis, structures, stability and utility J. Chem. Sci. 12123

13. Using $\mathrm{K}_{2} \mathrm{CO}_{3}$ (2 equiv.) at $140^{\circ} \mathrm{C}$ for $6 \mathrm{~h}$ and with similar molar quantities of the reactants product $\mathbf{A}$ (purity $>95 \%$ ) was isolated. Use of DABCO (2 equiv.) at $85^{\circ} \mathrm{C}$ for $20 \mathrm{~h}$, however, led to the isolation of the second isomer, product B. Tentatively assigned structures are shown below. Product A: M.p. $166-170^{\circ} \mathrm{C}$; IR $(\mathrm{KBr})$ : 3057, 2928, 1688, 1611, 1493, 1437, 1356, 1263, 1179, $1117,1073,723,696 \mathrm{~cm}^{-1} ;{ }^{1} \mathrm{HNMR}\left(400 \mathrm{MHz} \mathrm{CDCl}_{3}\right) \delta$ 7.83-7.80 (m, 2H), 7.54-7.20 (m, 13H), $6.70(\mathrm{~s}, 1 \mathrm{H})$, $4.18(\mathrm{~d}, J=8.2 \mathrm{~Hz}, 1 \mathrm{H}), 2.13(\mathrm{~s}, 3 \mathrm{H}), 2.05(\mathrm{~s}$, 3H), 2.04 (s, 3H). ${ }^{13} \mathrm{CNMR}\left(100 \mathrm{MHz}, \mathrm{CDCl}_{3}\right) \delta 198.7$, $151.6(J=5.1 \mathrm{~Hz}), 134.1(J=5.0 \mathrm{~Hz}), 132.8$, $132.5,131.9,131.8,131.6,131.5,131.2,131.1,131.0$, $130.1,128.7,128.6,128.5,128.3,128.23,128.18$, 128.1, 127.6, 57.1 $(J=64.7 \mathrm{~Hz}), 32.0,20.15$, 20.09, ${ }^{31} \mathrm{PNMR}\left(162 \mathrm{MHz}, \mathrm{CDCl}_{3}\right) \delta$ 30.3; LC/MS $\mathrm{m} / \mathrm{z}$ $375\left[\mathrm{M}^{+}+\mathrm{H}\right]$. Product B: gummy liquid; IR $(\mathrm{KBr})$ : 3052, 2932, 1677, 1595, 1490, 1436, 1353, 1178, $1118,1023,696 \mathrm{~cm}^{-1},{ }^{1} \mathrm{HNMR}\left(400 \mathrm{MHz}, \mathrm{CDCl}_{3}\right) 7.87-$ $7.71(\mathrm{~m}, 6 \mathrm{H}), 7.44-7.14(\mathrm{~m}, 10 \mathrm{H}), 6.95(\mathrm{~d}, J=$ $22.0 \mathrm{~Hz} 1 \mathrm{H}), 5.91(\mathrm{~s}, 1 \mathrm{H}), 2.10(\mathrm{~s}, 3 \mathrm{H}), 1.92(\mathrm{~s}, 3 \mathrm{H})$, $2.04(\mathrm{~s}, 3 \mathrm{H}) .{ }^{13} \mathrm{CNMR}\left(100 \mathrm{MHz}, \mathrm{CDCl}_{3}\right) \delta 199.1,153.8$ $(J=6.0 \mathrm{~Hz}), 135.3(\mathrm{~J}=5.0 \mathrm{~Hz}), 132.7,132.3$, $131.7,131.5,131.3,131.2,131.15,131.09,131.01$, 130.7, 130.6, 128.52, 128.49, 128.4, 128.2, 128.1, 127.3, $125.8,125.7,46.5(J=65.0 \mathrm{~Hz}), 32.1,23.5(\mathrm{~J}=$ $3.0 \mathrm{~Hz}) ;{ }^{31} \mathrm{PNMR}\left(162 \mathrm{MHz}, \mathrm{CDCl}_{3}\right) \delta 31.6 ; \mathrm{LC} / \mathrm{MS} \mathrm{m} / \mathrm{z}$ $375\left[\mathrm{M}^{+}+\mathrm{H}\right]$.
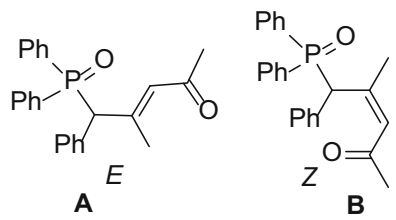

14. Sajna K V, Srinivas V and Kumara Swamy K C 2010 Efficient palladium-catalyzed double arylation of phosphonoalkynes and diarylalkynes in water: Use of a dinuclear palladium(I)-catalyst Adv. Synth. Catal. 352 3069
15. (a) Elumalai V, Sandtorv A H and Bjørsvik H R 2016 A Highly Efficient $\mathrm{Pd}\left(\mathrm{PPh}_{3}\right)_{4}$-Catalyzed suzuki crosscoupling method for the preparation of 2-nitrobiphenyls from 1-chloro-2-nitrobenzenes and phenylboronic acids Eur. J. Org. Chem. 1344; (b) Habashneh A Y, Dakhil O O, Zein A and Georghiou P E 2009 Efficient one-pot suzuki-miyaura double cross-coupling reactions using very low $\mathrm{Pd}\left(\mathrm{PPh}_{3}\right)_{4}$ catalyst loading Synth. Commun. 39 4221

16. (a) Kaishap P P, Duarah G, Sarma B, Chetia D and Gogoi S 2017 Ruthenium(II)-catalyzed synthesis of spirobenzofuranones by a decarbonylative annulation reaction Angew. Chem. Int. Ed. 56 1; (b) Tulichala R N P, Shankar M and Kumara Swamy K C 2017 Rutheniumcatalyzed oxidative annulation and hydroarylation of chromene-3-carboxamides with alkynes via double CH functionalization J. Org. Chem. 825068

17. Allu S and Kumara Swamy K C 2014 Rutheniumcatalyzed synthesis of isoquinolones with 8-aminoquinoline as a bidentate directing group in C-H functionalization J. Org. Chem. 793963

18. Allu S and Kumara Swamy K C 2015 Rutheniumcatalyzed oxidative annulation of 6-anilinopurines with alkynes via $\mathrm{C} \mathrm{H}$ activation: Synthesis of indole substituted purines/purine nucleosides Adv. Synth. Catal. 357 2665

19. Leela Siva Kumari A and Kumara Swamy K C 2016 Gold-catalyzed concomitant [3+3] cycloaddition/cascade heterocyclization of enynones/enynals with azides leading to furanotriazines J. Org. Chem. 811425

20. Siva Reddy A and Kumara Swamy K C 2015 Use of elemental sulfur or selenium in a novel one-pot coppercatalyzed tandem cyclization of functionalized ynamides leading to benzosultams Org. Lett. 172996

21. Siva Reddy A and Kumara Swamy K C 2017 Ethanol as hydrogenating agent: Palladium-catalyzed stereoselective hydrogenation of ynamides to give enamides Angew. Chem. Int. Ed. 566984 / Angew. Chem. 1297088

22. Anitha M and Kumara Swamy K C 2018 Synthesis of thiazolidine-thiones, iminothiazolidines and oxazolidines via the base promoted cyclisation of epoxysulfonamides and heterocumulenes Org. Biomol. Chem. 16402 